\title{
An Analysis Of Jargons Used By The Housekeeping Department At The Lovina Bali Hotel
}

\author{
Ni Luh Aristyawati ${ }^{1}$, I Gede Budasi², Nyoman Karina Wedhanti ${ }^{3}$ \\ 1,2,3Universitas Pendidikan Ganesha, Singaraja, Indonesia \\ e-mail: niluharistya24@gmail.com·yaysurya8@yahoo.com,karinawedhanti@yahoo.com
}

\begin{abstract}
Abstrak
Penelitian ini bertujuan untuk 1) mengidentifikasi jargon yang digunakan, 2) menganalisis pembentukan kata, 3) menjelaskan makna dari setiap jargon yang digunakan oleh Housekeeping Department di The Lovina Bali Hotel. Jargon yang digunakan oleh Departemen Housekeeping dianalisis masing-masing yang didasarkannkan oleh teori Allan dan Burriged (2006), teori Yule (2006) dan teori Hornby (1995). Penelitian ini adalah penelitian deskriptif kualitatif. Subjek penelitian ini adalah 3 staf Housekeeping. Instrumen yang digunakan dalam penelitian ini adalah ceklis, perekam suara, panduan wawancara. Studi ini menemukan 104 jargon yang digunakan oleh Housekeeping Department di The Lovina Bali Hotel. Jargon yang diklasifikasikan oleh peneliti menunjukkan bahwa ada 8 jenis pembentukan kata yang muncul dalam penelitian ini, frasa (46 data atau $4.23 \%$ ), abbreviation (37 or $35.57 \%$ ), kata benda (4 atau 3,84\%), kata kerja (2 atau 1,92\%), borrowing (2 atau 1,92\%), backformation (2 atau 1,92\%), kata sifat (1 atau 0,96\%), derivation (1 atau $0,96 \%$ ), dan kliping (1 atau $0,96)$.
\end{abstract}

Kata Kunci: Jargon; Housekeeping; The Lovina Bali

\section{Abstract}

This study aimed to 1) identify the jargons used, 2) analyze the word formations process, 3) explain the meaning of each jargons used by the Housekeeping Department at The Lovina Bali Hotel. Jargons is analyzed respectively based on the theories of Allan and Burriged (2006), Yule's theory (2006) and Hornby's theory (1995). This study was descriptive qualitative research. The subjects of this study were the 3 Housekeeping staff. The instruments that are used in this study were checklist, tape recorder, interview guide. This study found 104 jargons and showed that there are 8 types of word formation appears in this study, in the terms of phrases (46 or $4.23 \%$ ), abbreviations (37 or $35.57 \%$ ), nouns (4 or $3.84 \%)$, verbs (2 or $1.92 \%)$, borrowing (2 or $1.92 \%)$, backformations (2 or $1.92 \%$ ), adjectives (1 or $0.96 \%)$, derivation ( 1 or $0.96 \%$ ), and clippings ( 1 or 0.96 ).

Keywords: Jargon; Housekeeping; The Lovina Bali Hotel.

\section{Introduction}

The development of technology and science is progressing rapidly which makes some companies or departments need prospective workers who can master English well. In addition, because the needs of English in each professions are different (every profession has a certain English when communicating with their partners), it makes people required to learn specific English to develop their skills in their work. English for specific purpose language learning (ESP) is focuses on gaining professional expertise, which integrates disciplinary knowledge and professional practice according to different social situations in which most forms of special communication take place. English is taught to develop certain language skills using real situations in a way that allows them to use English in their future professions or to understand English discourse that relate to their field of specialization. There are three types of ESP, English for Science and Technology (EST), English for Social Studies (ESS) and English for Business and Economics (EBE). Each type is related to certain scientific fields of knowledge such as technology, economics, social fields and business industry.

One kind of business industry that required their workers to use English for specific purposes is hotel. Hotel is business industry that is engaged in services to hotel guests both physically, psychologically and security as long as the guests use the facilities or enjoy services at hotel (Agusnawar, 2000: 1). In hotel there are some departments such as engineering, front office, food and beverage, security, housekeeping, and etc. In each departments, it can be divided into several divisions. Each staff in the divisions in the hotel have their own language 
in communicating with their partner. The difference of the use of language make some people in community create their own new language variety according to their needs and purposes.

There are so many types of language variety which is used by the people in society. Jargon is one kind of them. According to Bolinger (through Pateda, 1987: 70) jargon is the use of language in every area of life. These areas of life include areas of expertise, positions, work environment, and each has a special language. The use of jargon is usually used in some field such as pilot, doctors, nursery, hospitality industry and etc. The function of jargon is to make some people easily while communicate with others in the same field.

Jargon is also used in hospitality industry especially in housekeeping departments. The housekeeping departments used jargons to communicate in doing some activity. For instance in housekeeping department, the definition of word holiday in general and housekeeping context is different. There are two meaning of holiday word. In dictionary, holiday is a day of recreation when no work is done, but in housekeeping context, the word holiday means a bed that is connected by a headboard. The use of jargons in the housekeeping department may often create misperceptions and misconceptions. People who do not have any background in housekeeping will difficult to understand about this jargon when they take part in the conversation among the housekeeping staff. The vocational high school students and undergraduate students who take concentration in tourism will rarely know jargons or maybe just a few of jargons because there is no book or dictionary that explain clearly about jargon and its meaning. As we know that textbooks always display vocabulary in focus if there is difficulty in understanding a dialogue or other description, Budasi (2019). These jargon will be very appropriate if they are put into language focus. According to Hutchinson and Walters, when the needs of the students have been identified, the next step is develop them into a develop material which consist of input and content. It makes authors easier in explaining the jargons that contained in Housekeeping.

Based on the phenomenon described above, the researcher conducted a research that concerning the jargons used by the Housekeeping Department at The Lovina Bali Hotel.This study was supported by some previous research that relate to jargon. Using empirical studies from previous research was needed to support the validity of the data. First, the study was conducted by Sitti Magfira Khumairah in 2017 entitled "Jargon Used by Baristas in Kopi Api Coffee Shop Makassar". This study was analyzed the form and the way of jargons used by Baristas in Kopi Api Coffee Shop Makassar in communication. The second research was conducted by Komang Tya Dwi Pradipta in 2017 entitled "An Analysis of Jargons Used by Receptionists in Front Office at Grand Istana Rama Hotel". This study aimed to identify and analyze the linguistic forms, meaning and describe the function of each jargon used in front office department at Grand Istana Rama Hotel. The third research was conducted by Ni Putu Repin Cemara Dewi in 2017 entitled "An Analysis of Jargon Used by Housekeeping Staff at The Westin Resort Nusa Dua". This study was analyzed the linguistics form, semantics content, function and specific context in which jargon is typically used among the housekeeping staff at the Westin Resort Nusa Dua.

Previous research has observed at the form, meaning, function, semantic content and how jargon is used. Therefore this study focuses on the meaning and the form of jargons viewed from their word formations. Thus, the researcher want to list and observe the jargons that used by the Housekeeping Department, forms of jargons viewed from their word formations and the meaning of the jargons used in the Housekeeping Department at The Lovina Bali Hotel.

\section{Concept of English for Specific Purpose (ESP)}

According to Tom Hutchinson and Alan Walters (1990), (English for Specific Purposes (ESP) is a language teaching approach that is based on students' decisions to learn about content and methods based on their needs. The same thing is also said by Robinson (1990), ESP is generally used to teach and learn foreign languages for clear utilitarian purposes and there is no doubt. While Mc Donough (1984) argues that ESP courses use a syllabus and material that is determined by all important things that have previously been analyzed about 
the communication needs of students. It means that ESP material refers to the needs of students.

\section{Concept of Jargon}

Allan and Burridge (2006: 56) define that jargon as a strange language in certain contexts such as profession, trade or other groups. Jargon used in the form of oral or written texts. Jargon is used by people who have similar interests regarding work. The use of jargon is not only for professionals, but also for group members who use certain jargon. Yule (2006: 211 ) says that jargon is a special technical vocabulary and expression used by a certain group of people or professions. Jargon helps maintain connections between those who see themselves as 'people in' a number of ways and to exclude 'outsiders' and it's difficult for others to understand. If people don't understand a certain jargon, it means that they are not part of the group. Jargon can be useful to convey an exact and very effective meaning for a community.

\section{Concept of Forms of Jargon}

The form of jargon is a combination of terms or physical appearance of a term that produces important technical meaning. Allan and Burridge (2006) state that jargon appears in two ways. First, it is formed in the form of new words. Second, it is formed in the form of existing words that are known by ordinary people.

\section{Concept of Word and Word Formation}

Allan and Burridge (2006) say that words are combination of sounds or speech sounds that are used as basic units in language and human communication that have meaning. Word consists of noun, adjective and verb. Word formation is a creation of a new word. According to Booij (2007), word formation is combining two or more meaningful language elements that will form a new form of two or more existing elements that were combined and regardless of the meaning of the elements that make it up. According to Yule (2010) word formation process is a word that has several forms, there are ten types of word formation such as: acronyms, abbreviations, borrowing, clipping, coinage, compounding, blending, backformation, conversion, derivation.

\section{Concept of Phrase}

Phrases are groups of words that consist of one word class and do not have a subject and verb which is a functional part of a longer speech (Venhaar, 1996: 291). According to Baker and O'Grady and Guzman, phrases can be classified into 5 types of words which are noun phrases, verb phrases, adjective phrases, prepositional phrases and infinitival phrases.

\section{Concept of Meaning of Jargon}

Meaning is what is referred to or indicated by e.g. sounds, words, or signals (Hornby, 1995: 726).

\section{Concept of Hotel}

According to Rumekso (2002: 2) hotel is a building that provides rooms for guests to stay, food and drinks, as well as other facilities needed and managed professionally to make a profit. There are seven departments in hotel according to Denney G. Rutherford (1990:15), there are Room Division Department, Personnel Department, Accounting Department, Marketing and Sales Department, Engineering Department, Purchasing Department and Food \& Beverage Department. Room Division Department divided into 5 divisions, there are front office, security, uniform service, telephone and housekeeping.

\section{Concept of Housekeeping Department}

Housekeeping Department is one of the most important departments in hotel, especially in the room division department. Rumekso (2002: 4) stated that housekeeping comes from the word house which means place to stay and keep which means take care of or 
maintaining. A housekeeper is a person who is in charge of, take care of and maintaining a house which in this case is a hotel.

\section{Methods}

This research was conducted in a qualitative research design. This research was conducted in The Lovina Bali Hotel. The Lovina Bali Hotel is located in Jl. Mas Lovina, Kalibukbuk, Lovina, Buleleng Regency, Bali. The subject of this research was the Housekeeping Department at The Lovina Bali Hotel. In this study, the researcher selected 3 Housekeeping Staff as informants. The object of this study is the jargons used by the Housekeeping Department at The Lovina Bali Hotel. The main instrument of this research is the researcher itself. The researcher use several instruments to obtain the data, there are checklist, tape recorder, and interview guide. Checklist here include many lists of jargons that the researcher has provided, their task is to mark what jargons that they often use while communicate with their partner. Through this checklist, the researcher is able to find out what jargons that are usually used by the Housekeeping Department.

\section{Finding \& Discussion}

This research found 104 jargons that were used by the Housekeeping Department at The Lovina Bali Hotel. The Housekeeping Department is divided into 6 divisions: room, public area, linen, valet, pool and laundry. There were several same jargons appear in different divisions. The jargons that were found in room are 92 jargons, in public area 15 jargons, in linen 14 jargons, in valet 9 jargons, in pool 12 jargons, and in laundry 17 jargons.

There were 6 types of jargons found viewed form their word formation, such as abbreviation, borrowing, clipping, compounding, back formation, derivation, and the rest of the jargons are in the form of words and phrase.

Table 1. Abbreviation

\begin{tabular}{llll}
\hline No. & Jargons & The Standard Form & \multicolumn{1}{c}{ Meaning } \\
\hline 1. & BT & Bath Towel & $\begin{array}{l}\text { A piece of cloth that is used for drying guest body } \\
\text { especially after bathing }\end{array}$ \\
2. & BB & Back to Back & $\begin{array}{l}\text { A group of guest that had previously stayed at a hotel } \\
\text { and then returned to check in } \\
\text { Special place for baby and it has a protector so the baby } \\
\text { doesn't fall to the floor }\end{array}$ \\
3. & BC & Baby Cot &
\end{tabular}

Based on the table 1, 37 or $35.57 \%$ data were found in form of abbreviation. The first example is 'BT'. 'BT' is the abbreviation for Bath Towel. 'BT' has experienced the process of reduction using the initialization of the word 'bath' + 'towel' $\rightarrow$ ' $B$ ' and ' $T$ '. Then, the two letters are joined into ' $\mathrm{BT}$ ' which means a piece of cloth that is used for drying guest body especially after bathing. Secondly, 'BB' is the abbreviation for Back to Back. 'BB' has experienced the process of reduction using the initialization of the word 'back' + 'to' + 'back' $\rightarrow$ ' $B$ ' and ' $B$ '. Then, the two letters are joined into 'BB' which means a group of guest that had previously stayed at a hotel and then returned to do check in. Thirdly, 'BC' is the abbreviation for Baby Cot. 'BC' has experienced the process of reduction using the initialization of the word 'baby' + 'cot' $\rightarrow$ ' $\mathrm{B}$ ' and ' $\mathrm{C}$ '. Then, the two letters are joined into BC which means a special place for baby and it has a protector so the baby doesn't fall to the floor.

Table 2. Borrowing

\begin{tabular}{ccll}
\hline No. & Jargons & Origins of words & \multicolumn{1}{c}{ Meaning } \\
\hline 1. & Heliconia & America & The name of the restaurant in the The Lovina Bali Hotel \\
2. & Lovina & Indonesia & The name of the hotel "The Lovina Bali Hotel" \\
\hline
\end{tabular}

Based on the table 2, 2 or $1.92 \%$ data were found in form of borrowing. Those data were heliconia and lovina. Heliconia is a type of flowering plant that comes from the Heliconiaceae family. Heliconia comes from the American language, because this plant is 
commonly found in America. Heliconia was chosen because of its unique name. Most of the garden in the hotel is also planted with this ornamental plants because its color is interesting. Then, the management of The Lovina Bali Hotel chose Heliconia as the name of the restaurant in The Lovina Bali. Lovina comes from the Indonesian language which means a beach on the northern part of Bali Island. Lovina was chosen because the location of the hotel is adjacent to the Lovina beach. Then, the management of The Lovina Bali Hotel chose Lovina as the name of the hotel in The Lovina Bali.

Table 3. Clipping

\begin{tabular}{llrl}
\hline No. & Jargon & $\begin{array}{r}\text { Base } \\
\text { Form }\end{array}$ & \multicolumn{1}{c}{ Meaning } \\
\hline 1. & As. & Assistant & $\begin{array}{l}\text { A person that works to support and helps the executive or manager } \\
\text { housekeeping }\end{array}$ \\
\hline
\end{tabular}

Based on table 3, there was found one datum or $0.96 \%$ in the form of clipping. 'As' for example is taken from the word assistant. The word assistant is formed by a process of backclipping or removing some of the syllables behind a word ('as' + 'sis' + 'tant') $\rightarrow$ 'As'. This clipping means a person that works to support and helps the executive or manager of housekeeping.

Table 4. Compounding

\begin{tabular}{cccl}
\hline No & Jargons & Origins of Words & \multicolumn{1}{c}{ Meaning } \\
\hline 1. & Clean-Up & Clean + Up & $\begin{array}{l}\text { General cleaning that is done only on certain times and } \\
\text { days such as hotel anniversaries }\end{array}$ \\
2. Landscape & Land + Scape & $\begin{array}{l}\text { Part of the garden which is neatly arranged and has a } \\
\text { value of beauty }\end{array}$ \\
\hline
\end{tabular}

Based on table 4, 8 data or $7.69 \%$ were found in the form of compounding. The example is 'Clean Up' is a combination the words 'clean' (adjective) and 'up' (adverb). Then, the two words are compounding into Clean Up which means a general cleaning that is done only on certain times and days such as hotel anniversaries.

'Landscape' is a combination the words 'land' (noun) and 'scape' (noun). Then, the two words are compounding into Landscape which means a part of the garden which is neatly arranged and has a value of beauty.

Table 5. Back Formation

\begin{tabular}{llll}
\hline No. & Jargons & $\begin{array}{c}\text { The Base } \\
\text { Form }\end{array}$ & \multicolumn{1}{c}{ Meaning } \\
\hline 1. & Consume & Consumption & $\begin{array}{l}\text { The food or drinks that has been eaten or drunk by the guest in } \\
\text { the minibar at hotel room }\end{array}$ \\
2. & Extent & Extension & $\begin{array}{l}\text { The guest lengthen their stay in hotel more than they planned } \\
\text { before in the beginning. }\end{array}$ \\
\hline
\end{tabular}

Based on the table 5, there were found 2 data with $1.92 \%$ in the form of back formation. The base form of the word consume is consumption. Consume is experienced the process of reducing words from one type to another type, 'consumption' $\rightarrow$ consume. Consume means the food or drinks that have been eaten or drunk by the guest in the minibar at hotel room. The base form of the word extent is extension. Extent is experienced the process of reducing words from one type to another type, 'extension' $\rightarrow$ extent. Extent means the guest lengthen their stay in hotel more than they planned before in the beginning. 
Indonesian Journal of Educational Research and Review, Vol 3 No 2, Tahun 2020

p-ISSN: 2621-4792, e-ISSN: 2621-8984

Table 6. Derivation

\begin{tabular}{llll}
\hline No. & Jargon & The Base Form & Meaning \\
\hline 1. & Landscaper & Landscape & A person who works to make a beautiful garden \\
\hline
\end{tabular}

Based on table 6 , one datum with $0.96 \%$ were found in form of derivation. The word landscape is the base form of the word landscaper. Landscape was added derivation which types of suffix (-er). Thus $\{$ landscape $\}+\{$-er $\} \rightarrow$ [Landscaper]. Landscaper means a person who works to make a beautiful garden.

Table 7. Word

\begin{tabular}{cccc}
\hline No. & Words & Categories & Meaning \\
\hline 1. & Cancel & Verb & The guest cancel to stay at the hotel \\
2. & Completing & Noun & The room attendant are finishing to make up the room \\
\hline
\end{tabular}

Based on table 7, 7 data or $6.73 \%$ were found in the form of words. Among those data, 2 data or $1.92 \%$ categorized as verbs, one datum or $0.96 \%$ categorized as adjective, and 4 data $3.84 \%$ categorized as nouns. Cancel is categorized as a verb. Cancel in the Housekeeping Department means the guest cancel to stay at the hotel. Completing is categorized as noun. Completing in the Housekeeping Department means the room attendant are finishing to make up the room.

Table 8. Phrase

\begin{tabular}{cccl}
\hline No. & Phrase & Categories & \multicolumn{1}{c}{ Meaning } \\
\hline 1. & Additional & Verb Phrase & $\begin{array}{l}\text { An extra cleaning is done because guests request to clean } \\
\text { his/her room again }\end{array}$ \\
2. Cleaning & American Style & $\begin{array}{c}\text { Noun } \\
\text { Phrase }\end{array}$ & $\begin{array}{c}\text { A bed style that is used to make a bed with blanket } \\
\end{array}$ \\
\hline
\end{tabular}

Based on table 846 data or $44.23 \%$ were found in form of phrase. There were 6 data or $3.40 \%$ in form of verb phrase, 2 data or $1.92 \%$ in form of adjective phrase and 38 data or $36.53 \%$ in form of noun phrase. Additional Cleaning is categorized as a verb phrase. The head of phrase "Additional Cleaning" is cleaning. It experienced the process of adding pre modifier 'additional' (adj) into the head 'cleaning' $(v)$. Then those words stand together into Additional Cleaning. In the Housekeeping Departments, it means an extra cleaning that was done because guests request to clean his/her room again. American Style is categorized as a noun phrase. The head of phrase "American Style" is style. It experienced the process of adding pre modifier 'American' $(n)$ into the head 'style' $(n)$. Then those words stand together into American Style. In the Housekeeping Departments, it means a bed style that is used to make a bed with blanket.

Table 9. The Result of Data Analysis

\begin{tabular}{cccc}
\hline No. & Word Formations & Amount & Percentage \\
\hline 1. & Abbreviation & 37 & $35.57 \%$ \\
2. & Borrowing & 2 & $1.92 \%$ \\
3. & Clipping & 1 & $0.96 \%$ \\
4. & Compounding & 8 & $7.69 \%$ \\
5. & Back Formation & 2 & $1.92 \%$ \\
6. & Derivation & 1 & $0.96 \%$ \\
7. & Verb & 2 & $1.92 \%$ \\
8. & Adjective & 1 & $0.96 \%$ \\
9. & Noun & 4 & $3.84 \%$ \\
10. & Verb Phrase & 6 & $5.76 \%$ \\
11. & Adjective Phrase & 2 & $1.92 \%$ \\
12. & Noun Phrase & 38 & $36.53 \%$ \\
& Total & 104 & $100 \%$ \\
\hline
\end{tabular}


Based on the table 9 , this study found in the terms of abbreviation (37 or $35.57 \%$ ), borrowing (2 or $1.92 \%)$, clipping (1 or 0.96$)$, compounding (8 or $7.69 \%)$, back formation (2 or $1.92 \%)$, derivation ( 1 or $0.96 \%)$, verb ( 2 or $1.92 \%)$, adjective ( 1 or $0.96 \%)$, noun ( 4 or $3.84 \%)$, verb phrase (6 or $5.76 \%$ ), adjective phrase (2 or $1.92 \%$ ) and noun phrase (38 or $36.53 \%$ ). Noun phrase is the most jargons that often be used by the Housekeeping Department at The Lovina Bali Hotel because most jargons are composed of phrases.

This study used Yule's theory which stated that there are ten types of word formation process, there are abbreviation, borrowing, coinage, clipping, compounding, blending, backformation, conversion, and derivation. Those word formation process are connected to the results of the finding in this study. It comes out that not all word formation process that stated by Yule appear in the Housekeeping Department. There were only seven types of word formation process appear, such as abbreviation, borrowing, clipping, compounding, backformation, and derivation. Thus, the results of this study was connected with the specific of English used by the Housekeeping Department that have certain language characteristics. It accordance with Tom Hutchinson and Alan Walters (1990) that stated ESP is a language teaching approach that is based on students' decisions to learn about content and methods based on their needs. Thus, the jargons that are used by the Housekeeping Department cannot be found in the other departments at Hotel, so that the results of this study represents English for specific purposes hospitality especially in the Housekeeping Department.

Furthermore, this study is dissimilar with the previous research because this study retrieve the data at The Lovina Bali Hotel that considered as 4 star hotel or commonly known as elite hotel in Singaraja, Bali. Besides, the previous study also used Yule's theory of word formation process but not all types of word formation process appear in the previous study. Thus, this study is generally supports the previous research related to jargons and also Yule's theory about word formation process. This current study is related to Ni Putu Repin Cemara Dewi in 2017 entitled "An Analysis of Jargon Used by Housekeeping Staff at The Westin Resort Nusa Dua", because this study takes the data in the Housekeeping Department. This study was analyzed the linguistics form used among the Housekeeping staff at the Westin Resort Nusa Dua. It is same with the current study that analyzed the word formation of jargons in Housekeeping Department. However the results of the previous and the currents study is different. The previous research found 145 types of jargons which were used among the Housekeeping staff at The Westin Resort Nusa Dua, there were in form of abbreviation (31 or $21.38 \%$ ) acronym (3 or $2.07 \%$ ), borrowing (14 or $9.65 \%)$, clipping (3 or $2.07 \%)$, verb (14 or $9.65 \%$ ), noun (18 or $12.42 \%$ ), adjective (7 or $4.83 \%$ ), noun phrase (52 or $35.86 \%$ ), and proportional phrase (3 or 2.07\%). Whereas the current study found 104 jargons in the Housekeeping Department and there were found noun phrase with amount (38 or 36.53\%). Noun phrase is the most jargons that often be used by the Housekeeping Department at The Lovina Bali Hotel because most jargons are composed of phrases. Based on the previous study and the results of this study, it can be concluded that all jargons in the Housekeeping Department was really used in hospitality in The Lovina Bali Hotel.

\section{Conclusion}

There were 104 jargons used in the Housekeeping Department at The Lovina Bali. Concerning the word formation process of jargons used by Housekeeping Department is investigated based on Yule's theory that appear such as such as abbreviation, borrowing, clipping, compounding, backformation, derivation, words and phrases.

Based on the result of this research, the researcher suggests some points of this research, the students of English Language Education should have better understanding on language variation especially jargon. This study will beneficial for ELE lecturers especially in order to give learning materials. It can be a sources while teaching and learning process that relate to language variation for developing basic material for ELE students especially in housekeeping. The Housekeeping Department can recognize their communication systems, so they can easily communicate effectively between housekeeping staff and they can also maintain their services to be better through their communication systems. 


\section{References}

Allan, K. A. (2006). Forbidden Words: Taboo And The Censoring Of Language. Cambridge: Cambridge University Press.

Astutik, Y. (2016). An Analysis On Jargon Used In Indonesia Lawak Klub (Ilk) Program On Trans 7. Univerisity Of Sidoarjo.

Baker, C. (1989). English Syntax. Cambridge: The Mit Pres.

Booij, G. (2007). The Grammar Of Words: An Introduction To Linguistic Morphology, 2nd Edition (Oxford Textbooks In Linguistics). Oxford: Oxford University Press.

Budasi, G. \&. (2019). English For Hotel. Singaraja: Mahima Institute Indonesia.

Critchfield, T. S. (2017). Normative Emotional Responses To Behavior Analysis Jargon Or How Not To Use Words To Win Friends And Influence People. Springer.

Dewi, N. P. (2017). An Analysis Of Jargon Used By Housekeeping Staff At The Westin Resort Nusa Dua. Singaraja: Undiksha.

Dewi, R. S. (2019). The Analysis Of Jargon Used By Whatsaap Community Among Tarbiyah Lecturers In Uinsu. Multi-Disciplinary International Conference University Of Asahan.

Donough, J. (1984). Esp In Perspective A Practical Guide. London: Collin Elt.

Emilda, F. (2017). An Analysis Of Word Formation In Jargon Used By Xiaomi Redmi Note 3 Pro Kaskus Forum. Universitas Islam Negeri Maulana Malik Ibrahim.

Guzman, O. A. (1996). Contempory Linguistics: An Introduction. United Kingdom: Essex.

Hornby, A. (1995). Oxford Advanced Learners Dictionary. New York: Oxford University Press.

Hutchinson, T. (1987). English For Specific Purposes: A Learning-Centered Approach. Cambridge: Cambridge University Press.

Jazuli, I. (2016). English Jargon Used By Front Office Staffs N Five Stars Hotel Surabaya. ERepository Widya Kartika.

Juddin, M. N. (2017). The Jargon Used By Employees Of Food And Beverage Service (Fbs Division) At Hotels. Let Journal.

Kangzhi Zhao, Y. Z., \& Xing, C. (2016). Chinese Underground Market Jargon Analysis Based On Unsupervised Learning. leee Conference On Intelligence And Security Informatics (Isi).

Khumairah, S. M. (2017). Jargon Used By Baristas In Kopi Api Coffee Shop Makassar. Makassar: Alauddin Islamic State University Of Makassar.

Maharani, N. (2016). Jargons Used By Judges, Mentors, And Host In Stand Up Comedy Academy. Surabaya: Uin Sunan Ampel Surabaya.

Maria Zimmermann, M. (2018). How Experts' Use Of Medical Technical Jargon In Different Types Of Online Health Forums Affects Perceived Information Credibility: Randomized Experiment With Laypersons. Journal Of Medical Internet Research .

Matias, G. S. (2017). The Study Of English Codes And Jargons Used By Fx Drivers Of Robinsons' Novaliches To Trinoma Mall Tripp. Ateneo De Manila University.

Milanda, N. S. (2019). Jargon Terms Used In Food And Beverage Department At The Highland Park Resort-Hotel Bogor. Universitas Pamulang Digital Repository.

Panellenaschnitzler, A. L. (2017). Communication During Radiation Therapy Education Sessions: The Role Of Medical Jargon And Emotional Support In Clarifying Patient Confusion. Elsevier, 112-120.

Pateda, P. D. (2001). Semantik Leksikal. Jakarta: Rineka Cipta.

Pradipta, K. T. (2017). An Analysis Of Jargons Used By Receptionists In Front Office At Grand Istana Rama Hotel. Singaraja: Undiksha.

Romadon, D. E. (2018). An Analysis Of Jargon Used In Malang Tattoo Community. Umm Instutional Repository.

Rumekso, S. (2002). Housekeeping Hotel Floor Section. Yogyakarta: C. V Andi Offset.

S Supardi, N. N. (2019). Positive Politeness Strategies Used In Conversation By Hotel. Dimensi.

Saputra, A. D. (2019). Analysis Of Hotel Jargon Used By Hotel Front Officers. Unika Soegijapranata Semarang.

Sompie, V. V. (2017). Jargon Terms Analysis Used In Housekeeping Department In Puri Denpasar Hotel Jakarta. Universitas Pamulang Digital Repository. 
Suhartawan Budianto, M. W. (2016). A Study Of Jargon Used On Food \& Beverage Division At The Alimar Premier Hotel Surabaya. Dinamika : Jurnal Sastra Dan Budaya.

Venhaar, J. (1996). Pengantar Linguistik. Yogyakarta: Gajah Mada University Press.

Wikrama, M. (2017). An Analysis Of Jargon Used By Receptionists In Front Office At Lovina Beach Hotel. Jurnal Pendidikan Bahasa Inggris Undiksha (Jpbi).

Yudha, I. P. (2018). An Analysis Of Jargon Used By Receptionists In Front Office At Asa. Lingua Scientia.

Yule, G. (1996). Pragmatics. Oxford: Oxford University Press. 2006. The Study Of Language Third Edition. Cambridge: Cambridge University Press. 